\title{
PENINGKATAN PENGETAHUAN, SIKAP, DAN PERILAKU HIDUP BERSIH DAN SEHAT PADA IBU RUMAH TANGGA DIMASA PANDEMI COVID-19
}

\author{
Sri Mustika Sari' ${ }^{1}$ Ade Saputra Nasution ${ }^{2}$ \\ 1,2Program Studi Ilmu Kesehatan Fakultas Ilmu Kesehatan Universitas Ibn Khaldun Bogor

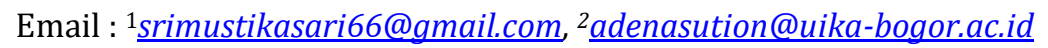

\begin{abstract}
Abstrak
PHBS dimasa pandemi sendiri merupakan salah satu bentuk upaya pencegahan penyebaran virus covid-19, banyak juga masyarakat yang meyakini bahwa fenomena Pandemi ini merupakan suatu konspirasi yang bertujuan untuk menguntungkan beberpa pihak sehigga banyak masyarakat yang acuh terhadap pentingnya PHBS selama pandemi. Kegiatan ini dilakukan dengan menggunakan metode kuantitatif dan mengumpulakn data melalui kuesioner dan observasi. Didalam kuesioner terdapat 30 pertanyaan dengan 3 variabel dimana diketahui bahwa pengetahuan ibu rumah tangga tentang PHBS selama masa pandemi covid masih sangat kurang (47\%), kemudian bagaimana sikap atau tanggapan ibu rumah tangga tentang PHBS dan covid-19 dikategorikan cukup (60\%), serta perilaku PHBS selama masa pandemi covid-19 dikategorikan kurang (53\%). Kemudian pada tahap observasi dapat disimpulkan bahwa terdapat sedikit peningkatan pengetahuan, sikap dan perilaku yang berarti bahwa kegiatan sosialisasi ini kuarng efektif. Maka dari itu besar harapan kepada pemerintah untuk meningkatkan kualitas PHBS dan melaksanakan kegiatan sosialisasi tentang wabah covid-19 pada masyarakat
\end{abstract}

Kata Kunci: Pengetahuan, Sikap, Perilaku, PHBS, Covid-19.

\section{PENDAHULUAN}

Covid-19 adalah penyakit yang disebabkan virus severe acute respiratory syndrome coronavirus 2 (SARS-CoV-2). Berdasarkan data pemerintah hingga Senin ini pukul 12.00 WIB (28 September 2020), terdapat 3.509 kasus baru Covid-19 dalam 24 jam terakhir. Penambahan itu menyebabkan jumlah kasus Covid-19 di Indonesia kini mencapai 278.722 orang, terhitung sejak diumumkannya kasus pertama pada 2 Maret 2020.

Berdasarkan data kasus pasien Covid-19 dari Kementerian Kesehatan RI hari ini 28 September 2020 sampai dengan pukul 12.00 WIB, total jumlah penambahan kasus Positif di Jawa Barat mencapai 489 orang, Sehingga akumulasi kasus positif di Jawa Barat sampai hari ini sebanyak 21.443 kasus. Jumlah kasus sembuh sebanyak 307 orang sehingga akumulasi kasus sembuh di Jabar sampai hari ini ada sebanyak 13.181 orang. Sementara itu, penambahan kasus meninggal dunia pada hari ini sebanyak 3 orang sehingga total akumulasi kasus meninggal dunia sampai hari ini sebanyak 390 kasus.

Juru bicara Pusat Informasi dan Kordinasi Covid-19 Kabupaten Cianjur Yusman Faisal menjelaskan bahwa semua pasien positif Covid-19 di Kabupaten Cianjur, Jawa Barat, telah dinyatakan sembuh, sehingga Cianjur kini dinyatakan nihil kasus corona. Dari lima kasus positif Covid-19, empat orang telah dikonfirmasi sembuh, sementara satu pasien lainnya meninggal dunia. Namun, kasus kematian terkait Covid-19 di Cianjur meningkat drastis dalam sebulan 
terakhir. Data pada Pusat Informasi dan Kordinasi Covid-19 Cianjur menunjukkan, hingga awal Juni 2020 tercatat 40 orang meninggal dunia. Data tersebut diperoleh dengan menghitung jumlah korban meninggal yang telah terkonfirmasi positif Covid-19, ditambah jumlah orang dalam pemantauan (ODP) dan pasien dalam pemantauan ( PDP) yang meninggal dunia sebelum hasil tes swab keluar. Juru bicara Pusat Informasi dan Kordinasi Covid-19 Yusman Faisal menyebutkan, untuk kasus kematian pasien positif Covid-19 tercatat ada satu orang.

Wabah Covid-19 yang disebabkan oleh severe acute respiratory syndrome-corona virus2 (SARS-CoV-2) telah menimbulkan kepanikan diseluruh dunia termasuk di Indonesia. Meskipun WHO, Centers for Disease Control and Prevention (CDC) maupun Kementrian Kesehatan RI telah mengeluarkan banyak informasi-informasi aktual dan panduan-panduan terkait Covid-19, tetapi berita-berita tidak sahih masih simpang siur yang tersebar di antara masyarakat. Padahal penularan virus ini dapat dicegah dengan menerapkan Perilaku Hidup Bersih dan Sehat (PHBS), seperti cuci tangan dengan baik dan benar, etika batuk, serta menjaga kesehatan dan sistem kekebalan tubuh.

Berdasarkan Riset Kesehatan Dasar tahun 2007, persentase rumah tangga yang mernenuhi kriteria PHBS dengan kategori baik secara nasional sebesar 38,7\%. Propinsi yang memiliki persentase di atas $38,7 \%$ ada 5 propinsi yaitu DI Yogyakarta (58,2\%), Kalimantan Timur (49,8\%), Jawa Tengah (47\%), dan Sulawesi Utara (46,9\%). Propinsi dengan persentase PHBS yang rendah adalah Papua $(24,4 \%)$, Nusa Tenggara Timur $(26,8 \%)$, Gorontalo $(27,8 \%)$, Riau $(28,1 \%)$ dan Sumatera Barat $(28,2 \%)$.

Dinas Kesehatan Provinsi Jawa Barat (2019) mencatat bahwa perilaku hidup bersih dan sehat (PHBS) di Jawa Barat angkanya masih cukup rendah. Edi Sutardi selaku Kasi Promosi dan Pemberdayaan Kesehatan Dinkes Provinsi Jawa Barat mengatakan berdasarkan angka kuantitatif, perilaku tidak sehat di Jawa Barat mencapai 61,8 \%.

Menurut penelitian Timisela (2007), mendapatkan tingkat pendidikan dan sikap adalah faktor paling dominan berpengaruh terhadap PHBS pada masyarakat Papua $(70,95 \%)$, Sedangkan hasil penelitian Zahara (2001) menemukan bahwa ada hubungan positif antara sikap terhadap perilaku hidup bersihdan sehat ibu dalam keluarga.

PHBS dimasa pandemi sendiri merupakan salah satu bentuk upaya pencegahan penyebaran virus covid-19, karena masih banyak masyarakat yang kurang patuh terhadap protocol kesehatan dari pemerintah, masih banyak masyarakat yang keluar rumah tanpa menggunakan masker, dan kurang nya kesadaran diri untuk selalu mencuci tangan. Banyak juga masyarakat yang meyakini bahwa fenomena Pandemi ini merupakan suatu konspirasi yang bertujuan untuk menguntungkan beberpa pihak sehigga banyak masyarakat yang acuh terhadap pentingnya PHBS selama pandemi.

Tujuan kegiatan ini untuk meningkatkan kesadaran masyarakat tentang pentingnya PHBS selama pandemi, karena banyak masyarakat yang kurang peka terhadap kebersihan khusunya lingkungan rumah tangga. Sasasaran utama dari kegiatan ini yaitu ibu rumah tangga sebagai role model dalam keluarga, karena ibu rumah tangga hampir setiap hari berada dirumah, sehingga bisa memudahkan penulis untuk melakukan edukasi tentang PHBS yang mana penulis mengharapkan ibu rumah tangga bisa meng-edukasi keluarganya untuk tetap menjaga kebersihan setiap hari baik didalam rumah maupun diluar rumah. 
Manfaat dari kegiatan ini adalah terbentuknya suatu lingkungan tatanan rumah tangga yang sehat dan bersih yang merupakan salah satu upaya pecegahan penularan virus covid-19

\section{METODE PENELITIAN}

Metode ini penulis lakukan dengan mengumpulkan data berdasarkan kuesioner, dan observasi dengan membagikan lembar presepsi yang merupakan salah satu jenis pengumpulan metode kuantitatif. Penelitian ini dilakukan melalui beberapa tahap dengan kurun waktu 3 minggu yaitu pada 5 September 2020 sampai 26 September 2020 dengan sasaran utamanya yaitu ibu rumah tangga yang berada dilingkungan RT04/RW04 Kp.Cikendi Desa Mekarjaya Kabupaten Cianjur.

Tahap pertama penulis meminta perizinan terlebih dahulu kepada RT untuk meminta menandatangani surat permohonan perizinan dan surat pernyataan kesediaan mitra. Kemudian penulis melakukan analisis situasi untuk mengetahui situasi dan kondisi msayrakat disana khususnya para ibu rumah tangga dengan didampingi oleh Kader setempat bernama ibu Simah (45). Di ketahui bahwa diligkungan RT tersebut tedapat 20 KK dimana 3 diantaranya sudah bercerai, 2 Cerai mati dan 2 sedang bekerja di Luar negeri menjadi TKW. Maka dari itu penulis menentukan 15 responden ibu rumah tangga dari 20 responden atas anjuran ibu kader.

Tahap kedua yaitu tahap pembagian lembar persetujuan dan pembagian kuesioner dengan metode door to door. Protokol kesehatan peneliti lakukan dengan tetap menggunakan masker dan menjaga jarak. Disini peneliti mendatangi responden satu persatu sebanyak 15 responden, kemudian penulis menjelaskan maksud dan tujuan dari kuesioner ini dan meminta persetujuan kepada responden untuk dijadikan sebagai responden kegiatan ini.

Tahap ketiga penulis melakukan sosialisasi mengenai seputar PHBS selama masa pandemi Covid-19, dengan menggunakan poster dari Kementrian Kesehatan dan Gerakan Masyarak Sehat (GERMAS) yang berjudul "Jaga Diri Dan Keluarga Anda Dari Virus Corona”

Tahap keempat yaitu penulis melakukan Observasi dan memberikan lembar penilaian presepsi karena dengan teknik ini penulis dapat melakukan pengambilan data secara relevan dan mengamati bagaimana perubahan responden setelah diberikan sosialisasi.

\section{HASIL PENELITIAN}

\section{Kuesioner}

Kami mengajukan 30 pertanyaan dengan 3 variabel, masing-masing variabel terdapat 10 pertanyaan, kemudian kami menentukan nilai rata-rata pada setiap variabel dalam kuesioner, dan mencari tahu pertanyaan mana yang paling banyak dijawab salah oleh responden. 
Tabel 1. Nilai Rata-Rata Pada Kuesioner

\begin{tabular}{|l|l|l|l|}
\hline No. & Variabel & Nilai rata-rata & No yang banyak menjawab salah \\
\hline 1. & Pengetahuan & $47 \%$ & $\begin{array}{l}\text { 6.Apakah anda tahu berapa langkah mencuci tangan } \\
\text { yang baik dan benar ? } \\
\text { 8. Apa dampak seseorang yang terpapar covid-19? } \\
\text { 9. Bagaimana cara penularan virus covid-19 }\end{array}$ \\
\hline 2. & Sikap & $60 \%$ & $\begin{array}{l}\text { 5.Apakah anda setuju covid-19 itu benar adanya? } \\
\text { 6. Apakah anda setuju covid itu berbahaya ? }\end{array}$ \\
\hline 3. & Perilaku & $53 \%$ & $\begin{array}{l}\text { 3. Seberapa sering anda mencuci tangan? } \\
\text { 4. Apakah saat anda pergi keluar rumah selalu } \\
\text { membawa handsanitizer? } \\
\text { 8.Apakah anda sering menggunakan masker saat } \\
\text { keluar rumah ? }\end{array}$ \\
\hline
\end{tabular}

\section{Observasi}

Setelah memberikan kuesioner dan melakukan sosialisasi kami melakukan observasi dan mebagikan pembagian lembar nilai presepsi sebagai tahap akhir dalam pengumpulan data, karena dengan teknik ini kami dapat melakukan pengambilan data secara relevan. Penulis bisa mengamati langsung kondisi responden ketika sebelum dan sesudah diberikan sosialisasi tentang perilaku hidup bersih dan sehat selama masa pandemi covid-19.

Tabel 2. Nilai Presepsi Masyarakat Setelah Dilakukan Sosialisasi

\begin{tabular}{|c|c|c|c|c|c|}
\hline \multirow[t]{2}{*}{ Variabel } & \multicolumn{2}{|c|}{$\begin{array}{c}\text { Sebelum } \\
\text { sosialisasi }\end{array}$} & \multicolumn{2}{|c|}{ Setelah sosialisasi } & \multirow[t]{2}{*}{ Keterangan } \\
\hline & $\mathrm{n}$ & $\%$ & $\mathrm{n}$ & $\%$ & \\
\hline \multicolumn{6}{|l|}{ Pengetahuan } \\
\hline Baik & 7 & $47 \%$ & 8 & $53 \%$ & \multirow{2}{*}{ Meningkat } \\
\hline Kurang Baik & 8 & $53 \%$ & 7 & $47 \%$ & \\
\hline \multicolumn{6}{|l|}{ Sikap } \\
\hline Baik & 10 & $67 \%$ & 10 & $67 \%$ & \multirow{2}{*}{ Tidak ada peningkatan } \\
\hline Kurang Baik & 5 & $33 \%$ & 5 & $33 \%$ & \\
\hline \multicolumn{6}{|l|}{ Perilaku } \\
\hline Baik & 6 & $40 \%$ & 10 & $67 \%$ & \multirow{2}{*}{ Meningkat } \\
\hline Kurang Baik & 9 & $60 \%$ & 5 & $33 \%$ & \\
\hline
\end{tabular}

\section{PEMBAHASAN}

Dalam pembahasan dari hasil kuesioner tersebut, diketahui bahwa pengetahuan ibu rumah tangga tentang PHBS selama masa pandemi covid masih sangat kurang (47\%), kemudian bagaimana sikap atau tanggapan ibu rumah tangga tentang PHBS dan covid-19 dikategorikan cukup (60\%), serta perilaku PHBS selama masa pandemi covid-19 dikategorikan kurang (53\%). Berdasarkan hasil kuesioner pertanyaan yang paling banyak dijawab salah pada 
variabel pengetahuan adalah No.6, 8 dan 9, yang artinya para ibu rumah tangga masih kurang pengetahuan nya tentang langkah-langkah mencuci tangan yang baik dan benar, kemudian mereka juga kurang mengetahui apa dampak dari seseorang yang terpapar dan bagaimana cara penularan covid-19. Kemudia di variabel sikap hampir semua menjawab salah pada pertanyaan No.5 dan 6 yang artinya bahwa para ibu rumah tangga kurang setuju tentang data peningkatan covid-19 yang sekarang dipublikasikan dan mereka juga memberikan sikap ragu-ragu bahwa covid ini merupakan suatu virus yang berbahaya. Yang terakhir jawaban yang paling banyak salah terdapat pada variabel perilaku yaitu pada No.3,4 dan 8 yang artinya bahwa para ibu rumah tangga masih kurang sadar tentang penting nya cuci tangan yang baik dan benar, selain itu juga kurang nya kesadaran untuk selalu membawa handsanitizer saat bepergian dan kurang nya kesadaran tentang penggunaan masker saat keluar rumah.

Hasil Observasi dan pembagian lembar nilai presepsi diketahui bahwa sebelum melakukan observasi, responden pada variabel pengetahuan berada diangka 47\% yang mana artinya sangat kurang sekali pengetahuan responden terhadap PHBS selama masa pandemi kemudian setelah adanya sosialisasi terdapat peningkatan menjadi 53\%. Kemudian pada variabel sikap responden berada dia angka 67\% setelah adanya sosialisasi tidak ada peningkatan yang berarti bahwa sikap atau tanggapan responden terhadap PHBS selama masa pandemi ini tetap sama. Selanjutnya pada variabel perilaku responden berada di angka 40\% kemudian setelah adanya sosialisasi meningkat menjadi $67 \%$ yang artinya bahwa terdapat perubahan perilaku responden setelah adanya sosialisasi.

\section{KESIMPULAN}

Dimasa pandemi seperti ini masyarakat perlu sadar akan pentingnya perilaku hidup bersih dan sehat. Karena dengan begitu kita bisa membantu meminimalisir penyebaran covid19 yang kian hari makin meningkat. Perilaku hidup bersih dan sehat merupkan suatu kegiatan yang dianjurkan oleh pemerintah sebagai salah satu bentuk pencegahan penyebaran virus corona, karena dengan kita meningkatkan PHBS kita maka akan tercipta juga lingkungan keluarga yang bersih dan sehat.

Dari hasil kegiatan ini dapat disimpulkan bahwa pengetahuan,sikap dan perilaku masyarkat khsususnya ibu rumah tangga sebagai role model keluarga masih sangat kurang,dan ternyata sosialisasi terhdap masyarakat itu perlu sekali dilakukan khususnya oleh pemerintah daerah setempat demi membantu meningkatkan pengetahuan, sikap dan perilaku masyarakat agar menerapkan kegiatan PHBS selama masa pandemi covid-19.

\section{DAFTAR PUSTAKA}

Azrimaidaliza, A., Nurmy, K., \& Edison, E. (2012). Pengetahuan dan Sikap Ibu Mengenai Perilaku Hidup Bersih dan Sehat di Keeurahan Koto Lalang. Jurnal Kesehatan Masyarakat Andalas, 7(1), 2-9.

Avianty, I., Luthfi, F., Suharto,, ...Ginanjar, R., Nasution, A.S. Nutritional status, dust exposure and risk factors for acute respiratory infections for workers in industrial estates. Indian Journal of Forensic Medicine and Toxicologythis link is disabled, 2021, 15(1), pp. 11561160 
AS Nasution, R Jayanti, A Nasution, DNA Nugroho, H Heru, EF Hutasoit. (2021). Contraceptive Use Among Women Of Reproductive Age And The Number Of Ideal Children In West Java. Jurnal Kebidanan dan Kesehatan Tradisional, 20-31.

AS Nasution, KN Oktalaksana, N Amalia, NR Azizah, S Rahmah, W Sari. (2021). Meningkatkan Kesadaran Masyarakat Ciwaringin Tanah Sewa Tentang Pentingnya Protokol Kesehatan Di Masa Pandemi Covid-19. JURNAL KREATIVITAS PENGABDIAN KEPADA MASYARAKAT (PKM) 4 (5), 1042-1049.

A Wulandari, I Sudrajat, K Agustika, MF Pribadi, R Deliana, S Atiqa, ... (2021). Hubungan Tingkat Pengetahuan Gizi dengan Status Gizi pada Mahasiswa Universitas Ibn Khaldun Bogor. Tropical Public Health Journal 1 (2), 24-27

AS Nasution. (2020). UPAYA PROMOTIF DAN PREVENTIF UNTUK MENGURANGI RISIKO YANG DITIMBULKAN OLEH ROKOK DI KELURAHAN RANCAMAYA. LOGISTA-Jurnal Ilmiah Pengabdian kepada Masyarakat 4 (1), 57-62.

APU Kusuma, A Nasution, AS Nasution. (2021). FAKTOR-FAKTOR YANG MEMPENGARUHI KEJADIAN KEKERASAN SEKSUAL TERHADAP SISWA DI SMA MUHAMMADIYAH KOTA BOGOR. PROMOTOR 4 (3), 192-198

AS Nasution. (2020). HYGIENE PENJAMAH MAKANAN MENYEBABKAN KONTAMINASI ESCHERICHIA COLI PADA JAJANAN PASAR TRADISIONAL. PROMOTOR 3 (1), 1-6

A Nasution, A Maulana, D Kurniawan. (2019). BERSAMA MEMAJUKAN DESA. Abdi Dosen: Jurnal Pengabdian Pada Masyarakat 3 (2), 99-104

Asri Masitha Arsyati, Vindi Krisna Chandra, 2020. Assement Kesiapan Kader Posyandu dalam Pelatihan Penggunaan Media Online. HEARTY Jurnal Kesehatan Masyarakat Vol.8 No.1, 2020 Agustus-February, hlm. 27-32 ISSN. 2338-7475 E-ISSN. 2620-7869

Fitrianingtyas, Pertiwi, dan Rachmania, W. Faktor-Faktor yang Berhubungan dengan Kejadian Kurang Energi Kronis (KEK) pada Ibu Hamil di Puskesmas Warung Jambu Kota Bogor. HEARTY Jurnal Kesehatan Masyarakat. 2018;6(2):1-8.

Irawati, E. (2011). Gambaran Karakteristik Keluarga Tentang Perilaku Hidup Bersih dan Sehat (PHBS) pada Tatanan Rumah Tangga di Desa Karangasem Wilayah Kerja Puskesmas Tanon II Sragen. Gaster, 8(2), 741-749.

MR Dilanti, AS Nasution. (2020). Pola Asuh Orang Tua dengan Perkembangan Sosialisasi dan Kemandirian Anak Usia 3-6 Tahun. Jurnal Bidan Pintar 1 (1), 1-10

Mariyamah ,S., Asri M. A., Ade Saputra N. (2020). Respon Mahasiswa Terhadap Pictorial Health Warning di Fakultas Teknik Universitas Ibn Khaldun Tahun 2020. Jurnal Mahasiswa Kesehatan Masyarakat. Vol. 3 No. 5

Nasution, A.S., Gurning, F.P., Pratama, M.Y., Fauzan,. Risk factors for diabetes mellitus occurrence in the elderly at the griya antapani public health center. Indian Journal of Forensic Medicine and Toxicologythis link is disabled, 2020, 14(1), pp. 1385-1389.

Nasution, A. S. (2020). Edukasi PHBS di Tatanan Rumah Tangga Untuk Meningkatkan Perilaku Sehat. Jurnal Abdidas, 1(2), 28-32.

Nasution AS. Aspek Individu Balita Dengan Kejadian ISPA Di Kelurahan Cibabat Cimahi. Amerta Nutr. 2020;4(2):103. 
Nasution A, Nasution AS. Puzzle Gizi sebagai Upaya Promosi terhadap Perilaku Gizi Seimbang pada Siswa. Media Kesehatan Masyarakat Indonesia. 2020;16(1):89-99.

Natsir, M. F. (2019). Perilaku Hidup Bersih Dan Sehat (PHBS) Pada Tatanan Rumah Tangga Masyarakat Desa Parang Baddo. Jurnal Nasional Ilmu Kesehatan, 1(3), 54-59.

Pertiwi, F. D., Hariansyah, M., \& Prasetya, E. P. (2019). FAKTOR RISIKO STUNTING PADA BALITA DIKELURAHAN MULYAHARJA TAHUN 2019. PROMOTOR, 2(5). https://doi.org/10.32832/pro.v2i5.2531

R Jayanti, AS Nasution. (2020). Analysis of Adolescent Sexual Behavior in Bogor Taruna Terpadu Borcess Middle School. Jurnal Ilmu Kesehatan Masyarakat 11 (01), 43-51

S Nurdiana, FD Pertiwi, E Dwimawati. (2021). FAKTOR-FAKTOR YANG BERHUBUNGAN DENGAN PENGALAMAN BULLYING DI SMK NEGERI 2 BOGOR PROVINSI JAWA BARAT TAHUN 2018. PROMOTOR 3 (6), 605-613

S Mariyamah, AM Arsyati, AS Nasution. (2020). RESPON MAHASISWA TERHADAP PICTORIAL HEALTH WARNING DI FAKULTAS TEKNIK UNIVERSITAS IBN KHALDUN TAHUN 2020. PROMOTOR 3 (5), 512-521

Suherdin,, Kurniawati, R.D., Nasution, A.S., Tualeka, A.R. Identification of related factors to safety behavior perception in pt. Kimia farma (persero) tbk. plant bandung. Indian Journal of Public Health Research and Developmentthis link is disabled, 2019, 10(12), pp. 20122016.

Tabi'in, A. (2020). Perilaku Hidup Bersih dan Sehat (PHBS) pada Anak Usia Dini sebagai Upaya Pencegahan Covid 19. JEA (Jurnal Edukasi AUD), 6(1), 58-73.

Yanuaringsih, G.P., Nasution, A.S., \& Aminah, S. (2020). Efek Seduhan Jahe Sebagai Anti Muntah Pada Perempuan Hamil Trimester I. Jurnal Kesehatan, 3, 151-158. 